PIOTR WOJTAS

ARTUR KOZŁOWSKI

MAREK WOJTAS

\title{
Digitization of Polish mining industry by reducing costs and improving safety and quality of finished product
}

\begin{abstract}
This paper presents the current level of digitization of the Polish mining industry on examples of copper and hard coal mines. A proposal to digitize the individual business processes in mining production was presented. Six basic components were defined: mineral deposit management, SOP (Sales and Operation Planning), production, machines, security, and analyses. These components define the specifics of the functioning of the mining process. New methods of collecting and processing data based on Big Data technology were proposed.
\end{abstract}

Key words: digitization, Big Data, safety, smart mine, Industry 4.0

\section{INTRODUCTION}

The restructuring of the Polish mining industry falls in the time of a new industrial revolution called Industry 4.0. Industry 4.0 sets a lot of store by the use of digital technologies, such as cloud computing, Big Data, or the Internet of things. The digital transformation of the economy is not only the condition of competitive efficiency but is slowly becoming a requirement to survive for Polish industrial organizations that compete for customers on a global scale.

In the global mining industry, mine management is carried out based on information acquired in real time. Data collecting from on-line measurements of the production processes and their analysis is one of Industry 4.0's attributes [1].

In the Polish mining industry, one can observe a dramatic increase in data acquired from technical systems and, on the other hand, increasing requirements concerning better management efficiency and work safety.

The majority of data acquired from technical systems is used only in systems that deal with measurements, monitoring the current state of the device, or parameters of the environment/process. Historical data is stored but used only occasionally (only to explain or analyze a particular event). This data is distributed and non-integrated, which makes it difficult or even impossible to conduct multi-criteria analyses or find mutual relationships between processes and events.

\section{EXPERIENCE AND COMPETENCE}

The partner companies of the CNP EMAG Group provide mines with devices, apparatuses, and measurement systems for conducting measurements within the range of:

- geophysics,

- gas measurement,

- mineral quality analysis.

In addition, the CNP EMAG partner companies provide telecommunication solutions for communication, alarms, and underground data transmission as well as the monitoring of the mining processes, personnel, and machines [2]. Thus, it is possible to say 
that the companies of the group have special competence and skills to develop and implement a system to collect, process, and analyze data from monitoring and control systems in real time.

Thanks to the use of sensors and advanced analytics, it will be possible to define suggestions and recommendations on how to improve business processes and regulations. This will result in higher production efficiency and better miner safety.

The developed system should provide a full picture of the supply chain, starting from deposit management and mining through coal preparation to its sale to customers. In addition, data analyses should enable us to optimize the energy and material efficiency of the production processes.

The results of a correlation analysis of machine parameters such as its motor rotations, temperature, and vibrations can be used to react to certain events and carry out prevention repairs. This will allow us to avoid unplanned work interruptions and ensure business continuity, which will positively impact mining output and reduce exploitation costs.

According to many experts, the Polish mining industry will achieve significantly higher management efficiency and better safety by employing information and communication technologies [3].

The digitization of the mining industry will allow us to achieve the assumed goals, provided that the competence and experience of the $R \& D$ staff of the CNP EMAG Group are combined with the best practices in the realm of mining processes and the available ICT (which have been successfully employed in many international mining corporation).

\section{MINING DIGITIZATION CONCEPT}

The results of $\mathrm{R} \& \mathrm{D}$ work that has been conducted for several years by the companies of the CNP EMAG Group have made it possible to define the Smart Mine Program, which is oriented towards the digitization of production management and safety in the mine [4].

While defining the program, the current digitization state of mining production was taken into account. This state is characterized by a lack of real co-operation between the business processes [3]. The following concerns have been observed:

- the employed ICT applications are isolated and distributed, and they come from many producers,
- there is not a model of integrated data coming from technical monitoring and control systems,

- many individualized Excel sheets are used, which results in a lack of data unification and synchronization,

- it is necessary to unify, collect, and consolidate data so it could be accessible in due time according to the requirements to make decisions in the realm of mining production.

The defined Smart Mine Program combines the following suggestions:

- an individual approach of CNP EMAG specialists to mining production through business processes, from the point of view of ICT,

- a solution that is a balance between modern technology and its possible application with respect to the existing conditions (political, human, and technological),

- using the knowledge of the personnel and a huge amount of collected data to find solutions that support current business processes but do not interfere with them,

- cooperation of companies from the mining environment with Polish mining corporations KGHM, PGG, and JSW in order to achieve success together,

- implementation of particular ICT solutions developed by different service and technology providers.

The key feature of the program is its interoperability. The products of the program will be able to function in compliance with other products or systems that already exist or may exist with no implementation restrictions [5].

The interoperability of the program will be achieved by securing the following goals:

- legal interoperability - in cooperation with certification bodies and the State Mining Authority in order to identify real solutions, certify them, and employ in mining,

- business interoperability - coordination of business processes and rules in the management range covered by the program,

- information and semantic interoperability - identifying a real information system with an unequivocal interpretation of data by systems used in the management range,

- technical interoperability - cooperation of many machines and devices with the use of the Internet of things, in compliance with the assumptions of the Industry 4.0 concept. 


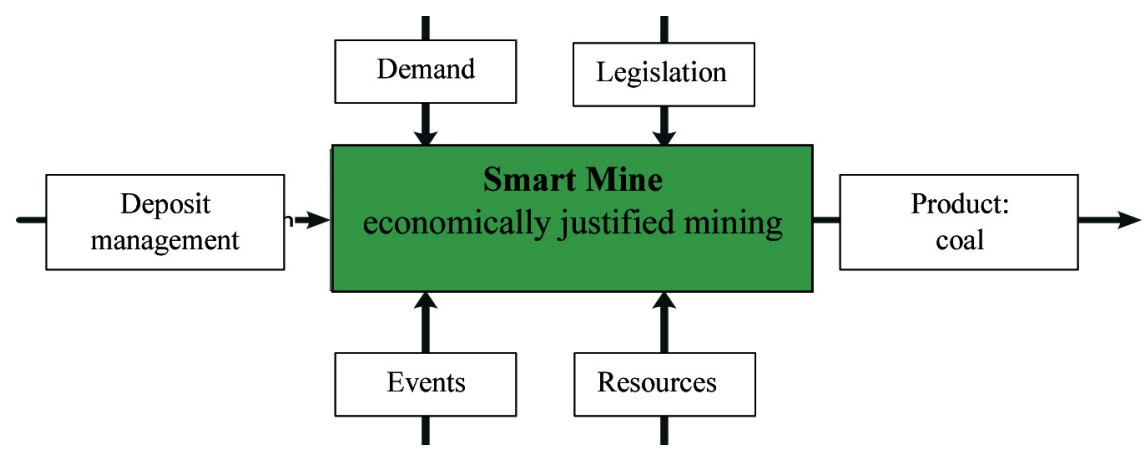

Fig. 1. Idea of Smart Mine Program

Figure 1 features the idea of the Smart Mine Program. It shows that the digitization of a mine should support the economically justified mining of minerals (in light of the existing demand and valid legal regulations) by means of the rational exploitation of the deposit and efficient use of resources, with respect to the existing natural hazards [6].

It is assumed that the program will be an important contribution to the transformation process of a mining management system.

In the course of the conducted work, the following specific tasks of the program were defined:

- higher efficiency of mining production management,
- better work safety,

- reduced production costs - not only in absolute values, but also as a percentage of product sales prices (coal, copper, and other mineral resources),

- better quality of the final product delivered to customers.

The digitization of the production management range and mine safety must be oriented towards key business processes taking place in a mine.

The business processes of a mining corporation are depicted in Figure 2, while Figure 3 shows which processes will be covered by the program.

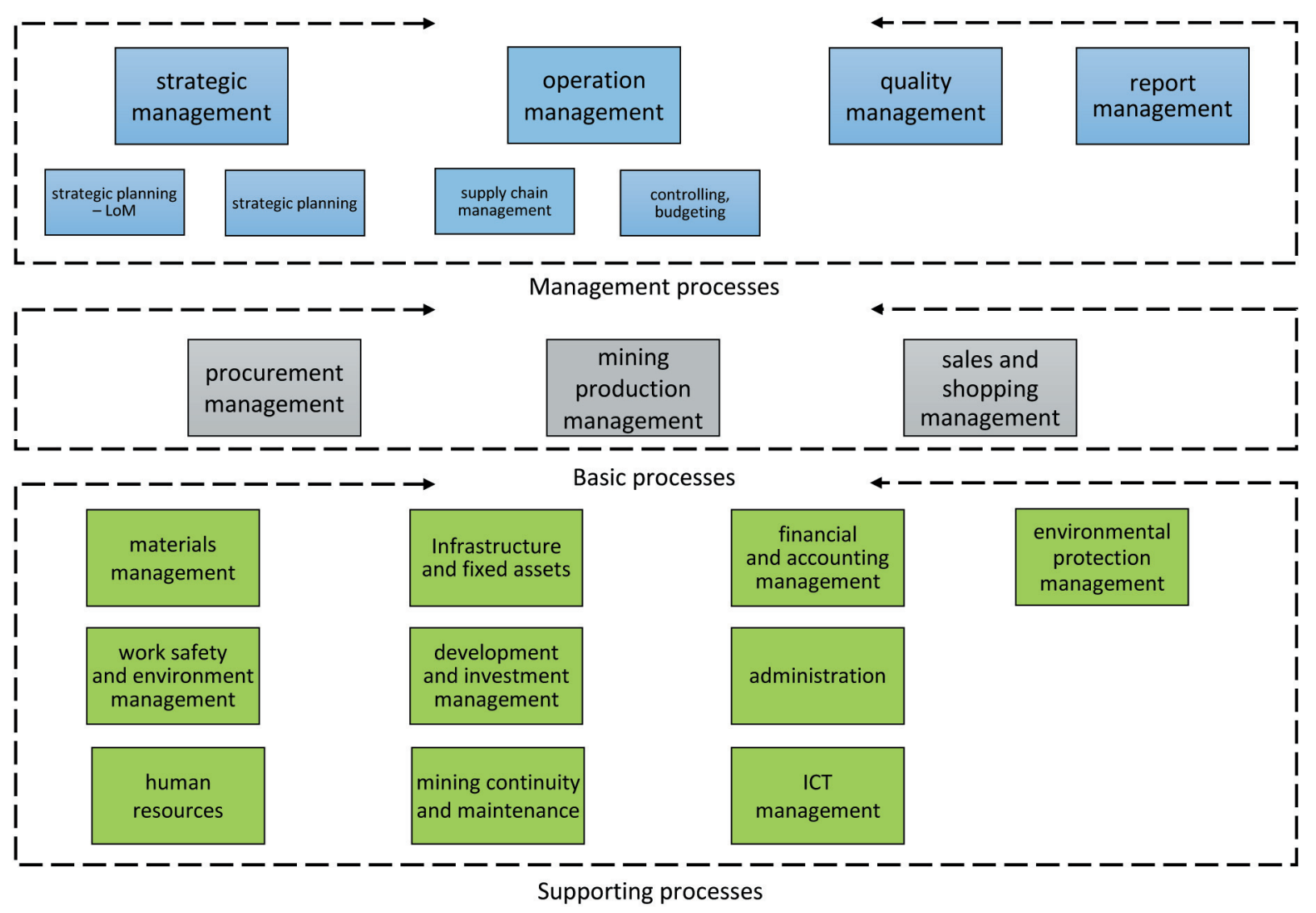

Fig. 2. Processes of mining corporation 


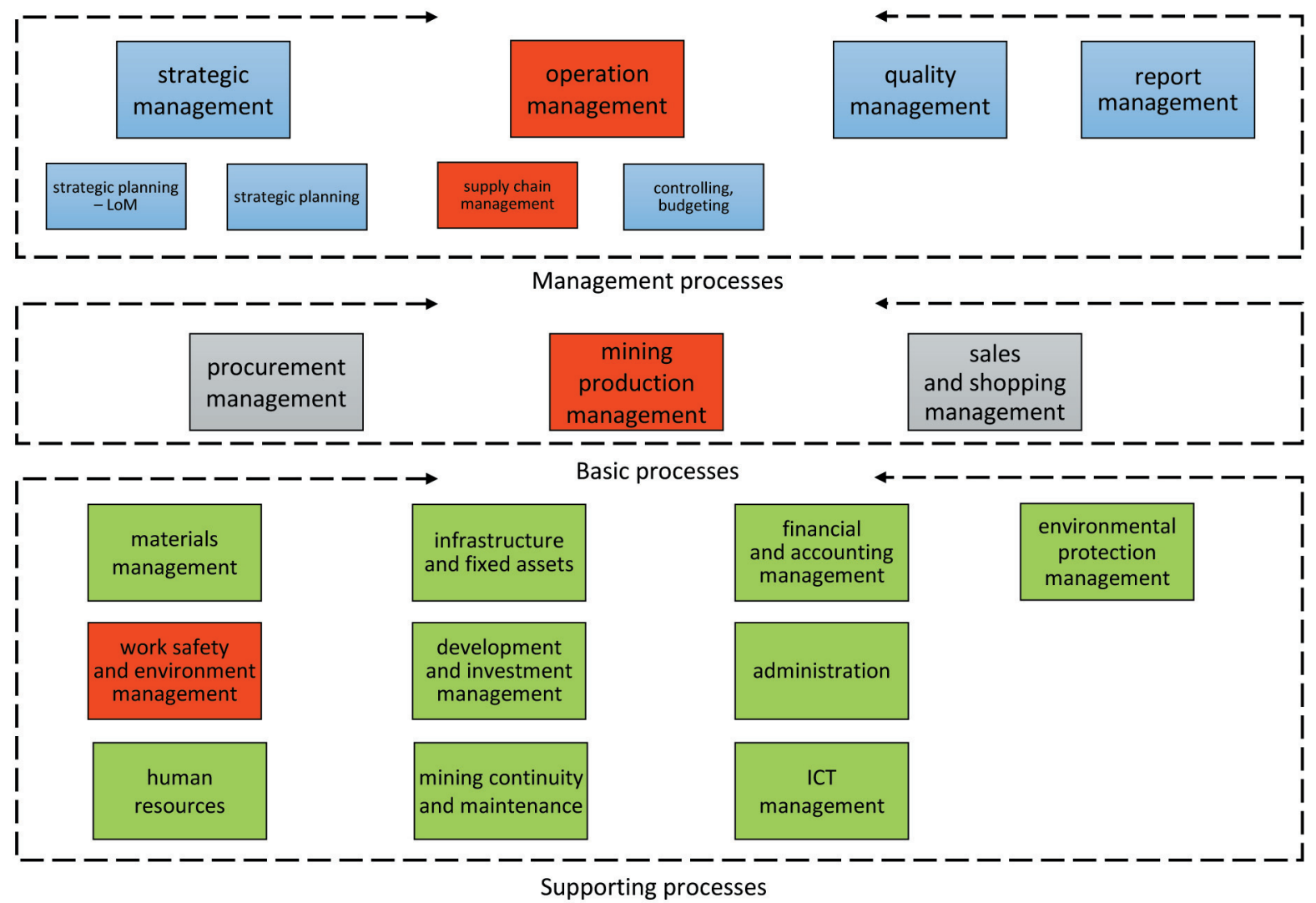

Fig. 3. Business processes covered by the Program - red color

It is important to note that the management processes and many functionalities of the other processes are conducted on the management level of the whole mining corporation, not only in the particular mines that are a part of it. Additionally, many of these functionalities are already supported by IT application systems; e.g., SZYK 2. The core of the program is the digitization of the business processes presented in Figure 3 [5].

These processes are marked in red, while the processes intensively supported by currently used IT systems and included in the program are marked with red shadows.

It was assumed that the program would encompass six functional components:

- Component 1 - Deposit/range: Deposit Management,

- Component 2 - SOP/range: Sales and Operation Planning - Supply Chain Management,

- Component 3 - Production/range: Mining Production Management,

- Component 4 - Machines/range: Infrastructure, Mining Continuity, and Maintenance,

- Component 5 - Safety/range: Safety Management,

- Component 6 - Analytics/range: TAS - Technical Analysis System.
Figure 4 presents the structure of the program and business processes related to the program components.

Each component of the program is strictly defined by the functionalities of the specific business processes. The program components will be developed as a result of the particular projects. One can assume that the functional range of a component will be worked out by one or several related projects.

It was assumed that particular functional components of the program would be developed by Poland's leading academic centers and institutes of the Polish Academy of Sciences as well as by the research institutes and companies working for the mining industry that have proper competence both in mining and ICT, the leading producers of mining machines, and the CNP EMAG Group.

Detailed functionalities of the components should be defined during the program-preparation phase. This work should be performed by previously selected contractors. It is important to note that, in the situation when the program is carried out by many contractors, it is necessary to ensure coherence with a view to achieving the program's objective.

The coherence of the solution will be ensured by the steering committee in charge of project management and by a model of business processes related to the area covered by the program. 


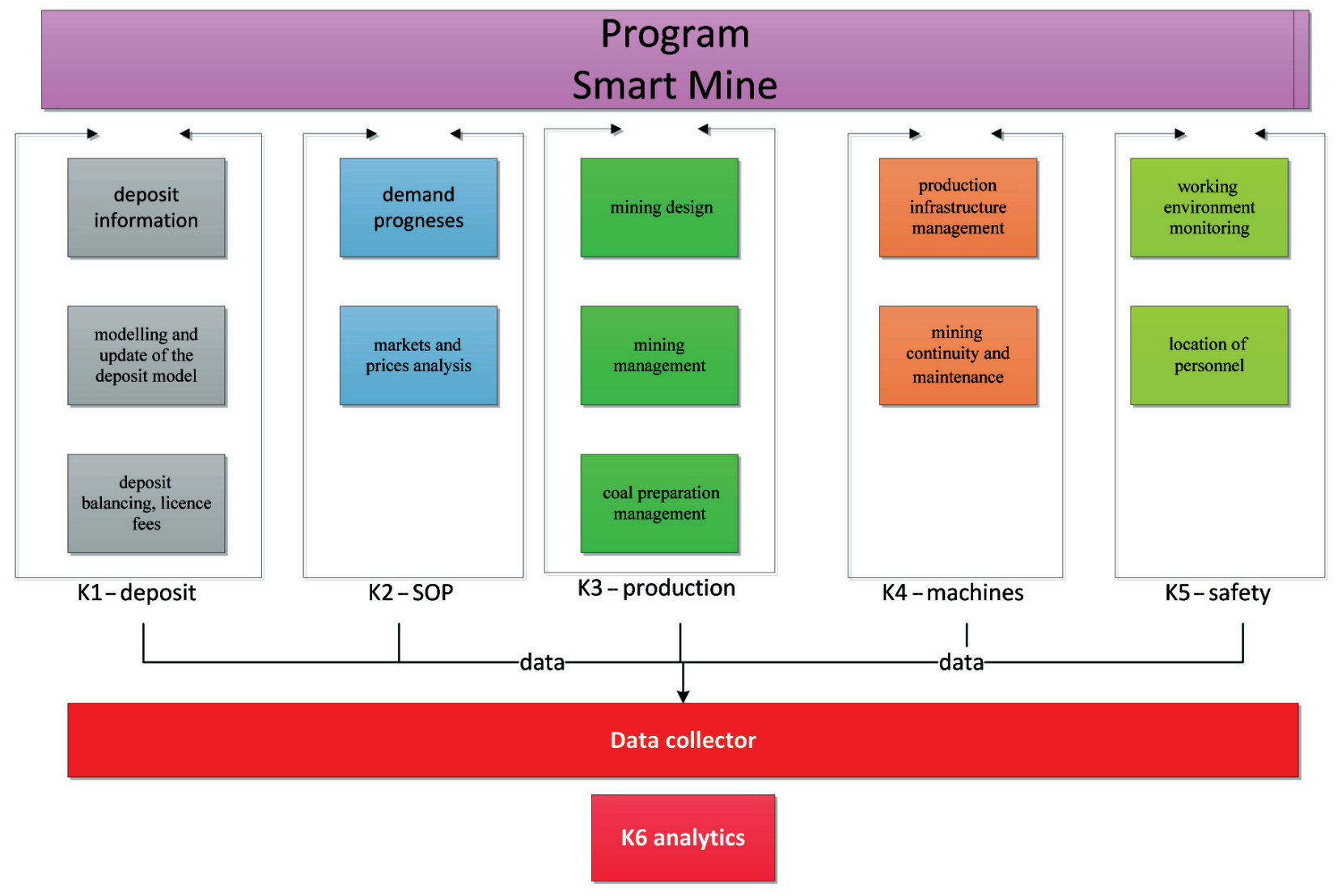

Fig. 4. Components and business processes of Smart Mine Program

Once the model of the processes is worked out by the project team, it should be accepted by the steering committee and taken up as the reference model. This model will determine the working range of the functional component developers. It will also be the basis for the constant development and improvement of the program.

The use of the business process reference model for mining production will enable us to fulfill the requirements in the range of corporate business interoperability.

The program's implementation is expected to bring the following results:

- increasing competence and efficiency in mining production management by synchronizing operations within the supply chain (from deposit management to coal shipment from the mine),

- giving access to tools for the rational management of resources and deposits by implementing complex planning procedures (from short-time schedules to multi-annual plans) and operation monitoring,

- reducing production costs and ensuring safe and proper working conditions by online analyses and monitoring of the operations,
- higher work efficiency by providing better air-conditioning parameters (temperature, dust concentration) in excavations,

- better work safety, for example, by limiting the time of the personnel's presence in particularly hazardous places (use of the Internet of things).

The expected financial effect of the program is a $5 \%$ reduction in the operational costs of processes in the realm of production and safety.

\section{TECHNICAL ANALYSIS SYSTEM}

With respect to the costs, complexity, and required preparation work for implementing the Mining Digitization Program, it is proposed to first start a project whose final product will be an analytical system that makes use of the data from systems currently exploited in the mines. This project will be based on the experience and competence of the CNP EMAG specialists. The developed system, called the Technical Analyses System (TAS), will result from carrying out the assumptions of the analytical component of the Smart Mine Program. 
Using the data from gas measurement, geophysics, minerals quality analysis, monitoring machines, and systems for locating people and devices, it will be possible to efficiently prepare and implement the first component of the program.

\subsection{Source data of TAS system}

It was assumed that the first stage of TAS system development would be oriented towards collecting, processing, and analyzing the structured data coming from gas measurement, geophysics, and machinemonitoring systems.

The key issue of the project in the first phase of TAS development is to work out a solution that would support the identification and evaluation of hazard levels in the mining environment, with respect to air composition and seismic events occurring in underground excavations.

The changing atmospheric parameters in mining excavations have to be controlled in terms of the socalled mining gas concentration and air flow. The parameters are continuously monitored by means of automatic gas measurement systems equipped with measurement sensors, data concentrators, and execution units. The data is transferred to surface supervision systems through data transmission systems.

Polish coal mines are estimated to have more than 4500 methane meters (average per mine: 120-150) with data registration. This number depicts the scale and complexity of the issue.

The seismic systems that are employed in Polish mines enable us to locate seismic events and determine the parameters of rock burst epicenters. Being familiar with the seismic parameters and layout of the measurement network makes it possible to use different algorithms of velocity and damping passive tomography. In tomography algorithms, the natural seismic phenomena invoked by mining exploitation are used. The system is equipped with software to perform passive tomography by means of probabilistic inversion. The credibility of the achieved results depends to a large extent on the number of bursts and their spatial layout.

The systems used in mines ensure the registration of data and messages in local databases. The databases are copied into several archives and used in monitoring and warning domain systems.

Taking into account the available measurement data from mining monitoring systems, it is suggested that such a TAS system should be developed that will extend the range of information use for business purposes. The system will be supplied with data acquired from mining systems for the monitoring and registration of technical data.

TAS will store a huge amount of data from gas and seismic monitoring systems. Hundreds of devices installed in the mines measure and monitor the methane concentration in the air (many online measurements), coal dust concentration, and the concentration of $\mathrm{CO}, \mathrm{CO}_{2}, \mathrm{H}_{2} \mathrm{~S}, \mathrm{NO}_{2}$, and $\mathrm{O}_{2}$ gases. In addition, the devices measure the velocity of air flow in order to assess the working conditions of the ventilation equipment, humidity, air temperature, rock temperature, equivalent temperature, or atmospheric pressure.

Similarly, measurement data is collected from several dozen two- and three-element seismometers and geophones. The data goes to supervisors - experts who supervise rock bursts in mines.

The TAS system will store a great amount of information in the realm of monitoring the operations and the technical conditions of the machines and devices. For example, in the PGG mining corporation, it would be necessary to collect data for:

- 8000 powered support units,

- 47 cutter loaders,

- 88 heading machines,

- 1300 transport systems,

- 270 underground trains.

The data from these measurements will be information input to the TAS system. TAS will also be provided with data acquired from external systems. It is assumed that the national European Plate Observing System (EPOS) will ensure complex unified data from particular domains (e.g., seismological, land surveying, and geological data) [7].

In the next phase of the TAS system development, there will be solutions developed to collecting, processing, and analyzing unstructured data, such as:

- geological maps,

- mining documentation (historical data),

- data generated by measurement and automation systems,

- location data generated by mobile devices for positioning people and machines,

- data from the Internet,

- photographs and scans,

- data from other systems. 
It is important to stress that the data collected in TAS will be characterized by a huge quantity and changeability in time as well as inestimable business value that can be obtained by analytics and reasoning.

The detailed range of the source data will be defined in the course of the project.

\subsection{TAS system technology}

It was assumed that the TAS system should collect both structured and unstructured data coming from mining technical systems and external data sources (e.g., EPOS). The storing, processing, and analytical tools of the system should enable us to acquire concrete information from this data, which is crucial for raising the efficiency of the business processes in a mining corporation.

First, the TAS system will be developed based on the Business Intelligence (BI) technology. The structure of such a system is presented in Figure 5. The developed analytical solution should enable advanced analyses and the application of prognostic methods.

Then, the range of the source data will be extended by unstructured data. This will require an extension of TAS by a new technology, according to the diagram in Figure 6. The Big Data technology will be applied.
The use of unstructured data makes it necessary to check whether it is possible to apply the Hadoop framework (open-source software) to develop one's own analytical environment that works with this sort of massive mining data. The work will be carried out with a view to developing a method of data linking in different formats and structures so it would be possible to identify the currently invisible relationships and dependencies. Based on the commonly used BI technology, it is not possible to process this type of unstructured data in a reasonable amount of time due to the lack of specialized analytical machines adapted to the expected size of the data sets and specific features of the analyzed mining issues.

The structure of the TAS solution includes a source data layer and layer of transactional data from measurement and monitoring systems. This data will be cleaned, integrated, and adapted to the requirements of a data workhouse with the use of the Extract, Transfer, and Load (ETL) requirements. In the proposed solution, it is assumed that the data will be loaded to the corporate data warehouse. The data in the warehouse comes from many sources, but it will be integrated and set as read-only. In case the data warehouse is significantly overcrowded with data (and to make the analytical work more efficient), data marts may be created.
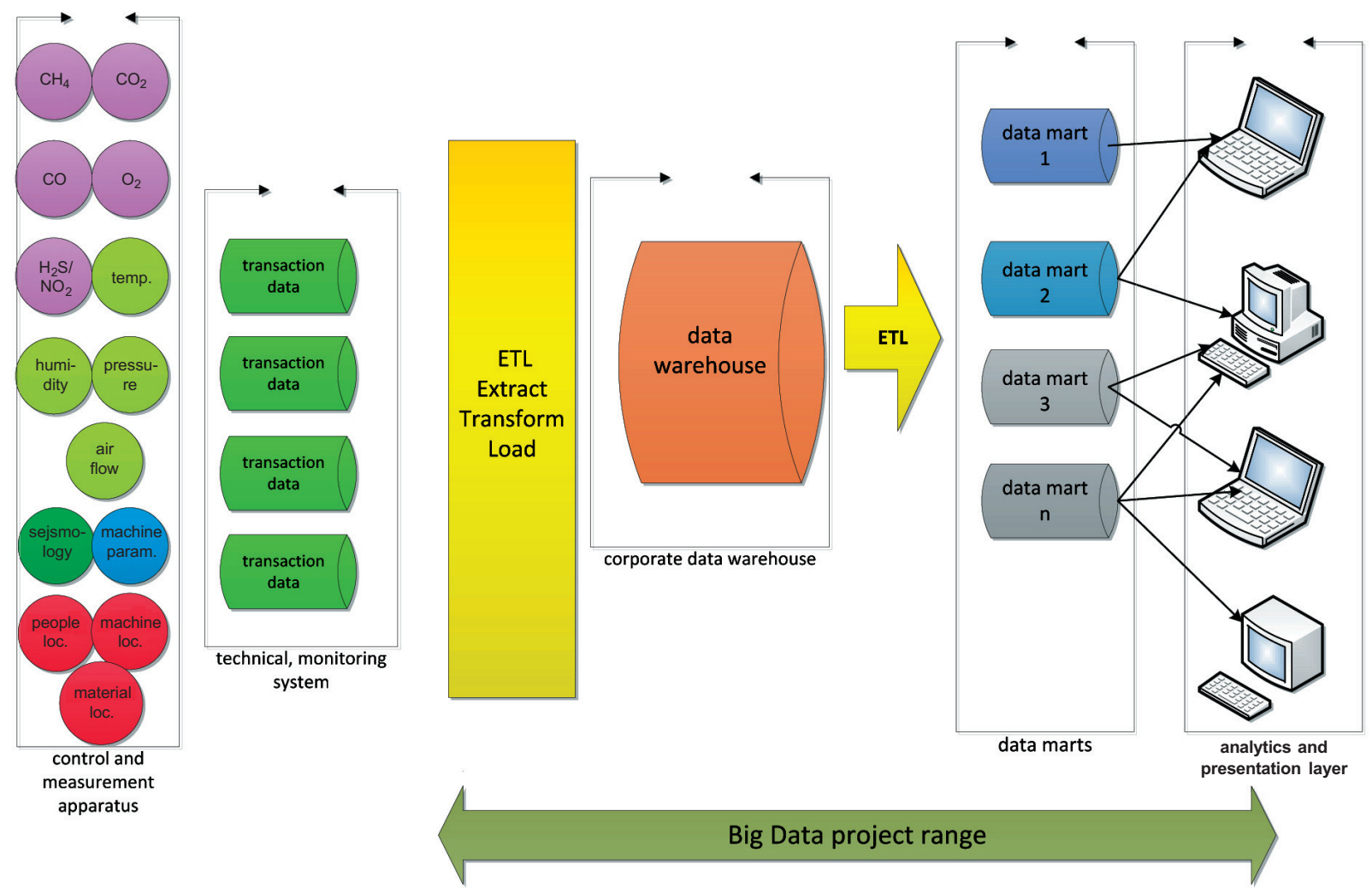

Fig. 5. TAS system in BI technology 


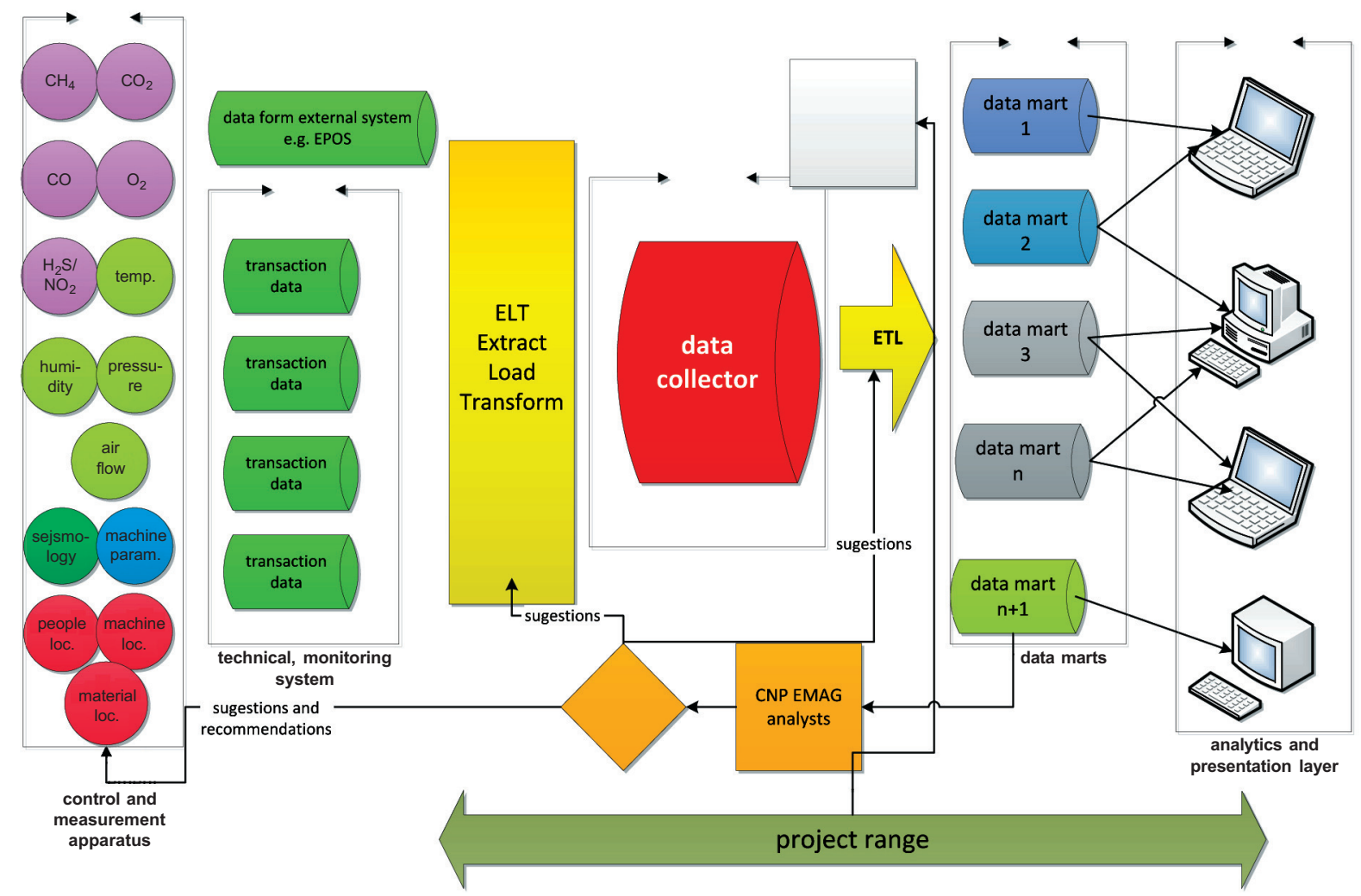

Fig. 6. TAS system in Big Data technology

There are two structures recommended for data storage in data marts:

- Database data mart - one dimensional base. Data processing and aggregation in an application (e.g., for reporting),

- Multi-dimensional structure - in the multi-dimensional structure, the data is ready for Online Analytical Processing (OLAP).

In the TAS system, data mining will be used to search for trends and dependencies. The technological solution based on the ELT process and data collector can be seen in Figure 6.

Data mining methods should enable us to identify cause-and-effect relationships that cannot currently be identified by means of proper technologies due to the huge amount of data to analyze. This will allow us to eliminate hazards in the mine and raise the efficiency of the business processes. The predictive model is usually based on historical data acquired from a data warehouse. The data is analyzed in the analytical module. However, the data needed for real-time prognoses must be available online, not in the periods resulting from the warehouse update cycles. Then, it is necessary to use the ELT (Extract, Load, Transform) process instead of ETL (Extract, Transform, Load) and to load source data straight to the data collector or data mart linked directly to the prediction support module.
The use of ELT is justified for saving and storing unstructured data in the TAS system collector according to the recommendations for the Big Data technology.

To develop TAS with the use of a technology applied in big data systems, it will be required to check whether it is justified to apply the following:

- MapReduce concept - Big Data platform - available in Hadoop/Apache Software Foundation, SAP HANA,

- Database (NoSQL), Apache Hbase - to save data streams,

- software to analyze huge sets of unstructured data - Apache Hadoop, SAP HANA (identifying dependencies and relationships for data in different formats and structures).

\subsection{TAS system analytics}

The TAS system should provide tools for the following:

- automatic reporting,

- data search and filtering,

- ad hoc analyses,

- data mining - drill-down, roll-up, drill-across, drill-through,

- construction of predictive models,

- file export to Excel. 
The possibility of exporting selected data files to Excel should meet the expectations of those analysts for whom Excel is the basic tool for analytical work.

Data mining will be widely used in TAS to search for trends and dependencies. The assessment of measurement results and the credibility of the analyzed data must be carried out with respect to the probable dynamics of changes in the measured quantity. This allows us to recognize the measurement result as credible or incredible. It is necessary to define rule and measurement assessment criteria so that the verification of the conducted evaluation accuracy could be possible only on the basis of the further progress of the process. In many cases (particularly those related to hazards), such an assessment must be made in real time. This situation imposes the quick reaction of the analytical system. The system associates the results of online measurements with historical data and works according to mining regulations. The collection of measurement data by the system and its frequency will be recommended for the measured quantities. Within this task, the applied rules of measurement aggregation will be verified. This refers to cases when a single measurement result represents the value of the measured quantity in a given period of time that is longer than the acquisition of measurement data (aggregation periods should result from mining practices and regulations).

Predictive modeling allows us to predict future results, estimate risk, assess the situation, and manage the processes in a general sense. Statistical analysis of representative portions of information available in the TAS system can improve the velocity and quality of the statistical predictive model's development.

Within the project, it would be necessary to select a predictive method for processes covered by the prediction. With quantitative predictive methods, it is possible to use such models as time series, econometrics, and cohort analysis with leading variables.

Qualitative methods are based on expert opinions and are formulated on the basis of data on the development of the variable predictive value and explanatory variables in the future.

A predictive method should be selected on the basis of the assumed prerogatives and available historical data. At the current stage of defining the range of the research project, one can recommend quantitative methods based on time series. However, with better predictive experience and a greater amount of unstructured data, it will be possible to use qualitative methods. The model's development will be supported by the prediction support module. In the period when the prognoses are used, it is necessary to assess their accuracy by means of ex-post errors. The prediction results will be presented in tables and predictive value diagrams. The predictive module should be supplied with real values that can be compared with the prognosis.

\subsection{Data Analysis Center}

The analytical component of the TAS system will process the collected information and enable reasoning based on the implemented models.

TAS should be treated as an auxiliary tool in the decision-making processes related to technical issues.

It is assumed that the development and implementation of the Smart Mine Program products (in particular, the implementation of the TAS system) will be related to the start of the Data Analysis Center (DAC). DAC will conduct advanced analyses of data collected from monitoring the process of mining production and the working conditions of the miners.

DAC will require work performed by experts from different organizations (universities, research institutes, State Mining Authority, mining companies) with adequate knowledge of the subject.

Today's ICT technologies enable remote access to data and remote real-time monitoring of processes by distributed teams of analysts.

The analysts of DAC should:

- be able to conduct analyses of Big Data sets with structured and unstructured data,

- understand the behavior of machines as well as measurement networks and systems to identify unusual/atypical events and cases without generating false alarms,

- be able to model prognoses and simulations,

- be able to interpret the results and prognoses in light of domain knowledge, knowledge of processes, and regulations.

The DAC Center will offer expert services (analyses, modeling, prediction) for Big Data. The services will be calculated on the basis of a billing system that will register the performed work. The relationships between DAC and TAS can be seen in Figure 6. 


\section{CONCLUSIONS}

The concept of the gradual digitization of the Polish mining industry discussed in the article is an attempt to propose a complex solution to support the management, production, and safety processes in mines. The solution will allow us to optimize the use of machines and devices in the production cycle as well as plan renovations and investments with high accuracy. It will also improve work safety in underground mines. A system-based approach to production and safety management with respect to quantitative and qualitative economic aspects is particularly important for Polish mining, which has been undergoing restructuring processes for years.

A good example of the first stage of a mine digitization is the One Control Room concept in the Polkowice-Sieroszowice copper mine (a part of the KGHM corporation). This concept is a new approach to data acquisition and processing. It enables the remote control of the production and maintenance processes and offers a proactive approach to the maintenance of systems, which ensure lower exploitation costs and better quality of the final product [8].

Due to the fact that processing bigger and bigger data sets has become something common in business, it is necessary to perform the next stage of mining digitization; i.e., developing a system for Big Data analyses along with a data analysis center. Finding the dependencies and correlations between the data coming from different areas of basic and supporting processes in a mine will become a perfect source of management and maintenance information. It will also allow us to impact the production process and quality of the final product required by the customer. Another equally important element is the method of presenting the above information with respect to the perceptive abilities of production management personnel.

\section{References}

[1] Kozłowski A., Wojtas P.: Systemowe podejście do cyfryzacji w procesach technologicznych w górnictwie, "Szkoła Eksploatacji Podziemnej", Kraków 2017.

[2] Kozłowski A.: Bezpieczeństwo procesów technologicznych $w$ ujęciu systemowym. Zintegrowany system zarządzania Silesia +, Kongres Innowacji Polskich, Kraków 2015.

[3] Stach R., Borkowski L.: One control room w ZG Polkowice-Sieroszowice, IMF, Jastrzębie-Zdrój 2017.

[4] Kozłowski A., Wojtas P.: Możliwość optymalizacji procesów technologicznych zakładu górniczego w kontekście cyfryzacji górnictwa, Polski Kongres Górniczy, Kraków 2017.

[5] Goleń A., Gałuszka J., Wojtas P., Wojtas M.: Studium Wykonalności Programu Cyfrowa Kopalnia/ Smart Mine, opracowanie własne CNP EMAG S.A., Katowice 2017.

[6] Wojtas P., Goleń A.: Optymalizacja procesów wydobywczych poprzez cyfryzację kopalni, IMF, Jastrzębie-Zdrój 2017.

[7] European Research Infrastructure on Solid Earth - https:// www.epos-ip.org/.

[8] Andrzejewski M., Borkowski L.: Kierunki rozwoju monitoringu pracy maszyn $i$ urządzeń górniczych w KGHM "Polska Miedż” S.A., "Wiadomości Górnicze” 2014, 10.

PIOTR WOJTAS, Ph.D., Eng. Science and Industrial Centre EMAG Inc. ul. Karoliny 4, 40-186 Katowice, Poland piotr.wojtas@cnp-emag.pl

ARTUR KOZŁOWSKI, Ph.D., Eng. Institute of Innovative Technologies EMAG ul. Leopolda 31, 40-189 Katowice, Poland artur.kozlowski@ibemag.pl

MAREK WOJTAS, M.SC. Telvis Ltd. ul. Karoliny 4, 40-186 Katowice, Poland marek.wojtas@telvis.pl 


\title{
Cyfryzacja polskiego górnictwa metodą obniżenia kosztów i zwiększenia bezpieczeństwa oraz jakości produktu końcowego
}

\begin{abstract}
$W$ artykule przedstawiono aktualny poziom cyfryzacji polskiego górnictwa na przykładzie kopaln miedzi i węgla kamiennego. Przedstawiono propozycję digitalizacji procesów biznesowych $w$ obszarze produkcji górniczej. Zdefiniowano sześć komponentów opisujacych specyfike funkcjonowania procesów zachodzacych $w$ kopalniach: zarzqdzanie złożem, SOP (Sales and Operation Planning), produkcja, maszyny, bezpieczeństwo i analizy. Zaproponowano nowe metody zbierania i przetwarzania danych $z$ wykorzystaniem technologii Big Data.
\end{abstract}

Słowa kluczowe: cyfryzacja, Big Data, bezpieczeństwo, inteligentna kopalnia, przemyst 4.0

\section{WPROWADZENIE}

Proces restrukturyzacji polskiego górnictwa przypada na moment rozwoju kolejnej rewolucji przemysłowej zwanej Przemysłem 4.0. Przemysł 4.0 kładzie szczególny nacisk na wykorzystanie technologii cyfrowych, takich jak chmura obliczeniowa, Big Data czy Internet Rzeczy. Cyfrowa transformacja gospodarki jest nie tylko warunkiem skutecznego konkurowania, ale powoli staje się elementem przetrwania polskich przedsiębiorstw przemysłowych walczących o klientów w skali międzynarodowej.

W światowym górnictwie zarządzanie kopalnią jest realizowane na podstawie informacji uzyskiwanych w czasie rzeczywistym. Gromadzenie danych z ciagłych pomiarów procesów produkcji i ich analizowanie jest jednym z atrybutów koncepcji Przemysł 4.0 [1].

W polskim górnictwie radykalnie rośnie ilość danych pozyskiwanych z systemów technicznych, a z drugiej strony ciągle zwiększają się wymagania dotyczące wzrostu efektywności zarządzania i poprawy bezpieczeństwa pracy.

Większość danych pozyskiwanych z systemów technicznych jest wykorzystywana jedynie w systemach, które bezpośrednio obsługują pomiary, monitorują stan bieżący urządzenia lub parametry środowiska/ procesu. Dane historyczne są przechowywane, ale wykorzystywane są sporadycznie, jedynie w celu wyjaśnienia lub analizy konkretnego zdarzenia. Dane te są rozproszone, niezintegrowane, co utrudnia bądź uniemożliwia przeprowadzanie wielokryterialnych analiz i szukanie wzajemnych powiązań pomiędzy procesami oraz zdarzeniami.

\section{DOŚWIADCZENIE I KOMPETENCJE}

Firmy partnerskie Grupy CNP EMAG dostarczają do zakładów górniczych urządzenia, aparaturę i systemy do przeprowadzania pomiarów w zakresie:

- geofizyki,

- gazometrii,

- analizy jakości kopalin.

Ponadto firmy Grupy CNP EMAG dostarczają rozwiązania telekomunikacyjne dla łączności i alarmowania, podziemnej transmisji danych oraz monitorowania procesów wydobywczych, pracowników i maszyn [2]. 
Można zatem stwierdzić, że firmy Grupy mają szczególne kompetencje i predyspozycje do opracowania i wdrożenia systemu gromadzenia, przetwarzania i analizowania danych z systemów monitorowania i sterowania, realizowanego w czasie rzeczywistym.

Dzięki zastosowaniu czujników i zaawansowanej analityce będzie można formułować sugestie i rekomendacje w celu usprawnienia procesów biznesowych i reguł postępowania, co będzie skutkowało wzrostem efektywności produkcji oraz poprawą bezpieczeństwa pracy górników.

Zbudowany system powinien dostarczyć pełnego obrazu łańcucha dostaw, począwszy od zarządzania złożem i wydobyciem po przygotowanie urobku do sprzedaży klientowi końcowemu. Analizy danych powinny ponadto umożliwiać optymalizację efektywności energetycznej i materiałowej procesów produkcyjnych.

Wyniki analiz korelacji parametrów maszyn, takich jak obroty silnika, jego temperatura, drgania, będa mogły być wykorzystane do reagowania i prowadzenia napraw prewencyjnych. Pozwoli to unikać nieplanowanych przerw w pracy i zapewnić utrzymanie ruchu, co pozytywnie wpłynie na zwiększenie wydobycia i redukcję kosztów eksploatacji.

Zdaniem wielu ekspertów polskie górnictwo, stosując technologie ICT (Information and communications technology), osiagnie znaczący wzrost efektywności zarządzania i poprawy bezpieczeństwa [3].

Cyfryzacja górnictwa pozwoli na osiągnięcie założonych celów, jeśli kompetencje i doświadczenie pracowników działów badań i rozwoju (R\&D) zatrudnionych w Grupie CNP EMAG zostaną połączone z dobrymi praktykami dotyczącymi procesów górniczych oraz dostępną technologią ICT, która jest już intensywnie stosowana w wielu światowych korporacjach górniczych.

\section{KONCEPCJA CYFRYZACJI GÓRNICTWA}

Wyniki prac badawczo-rozwojowych prowadzonych od kilku lat w firmach Grupy CNP EMAG umożliwiły zdefiniowanie Programu „Cyfrowa Kopalnia” (Smart Mine), zorientowanego na cyfryzację obszaru zarządzania produkcją i bezpieczeństwem kopalni [4].

Definiując program, wzięto pod uwagę obecny stan cyfryzacji obszaru zarządzania produkcją górniczą, który charakteryzuje brak realnej kooperacji pomiędzy procesami biznesowymi [3].
Stwierdza się bowiem:

- stosowanie odcinkowych, rozproszonych aplikacji ICT, pochodzących od wielu dostawców,

- brak wdrożenia korporacyjnego modelu zintegrowanych danych pozyskiwanych $\mathrm{z}$ technicznych systemów monitorowania i sterowania,

- stosowanie dużej liczby zindywidualizowanych arkuszy kalkulacyjnych Excel, co prowadzi do braku unifikacji i synchronizacji danych,

- konieczność ujednolicenia, gromadzenia i skonsolidowania danych, aby je udostępniać zgodnie $\mathrm{z}$ wymaganiami, w czasie ustalonym do podejmowania decyzji w obszarze zarządzania produkcją górniczą.

Zdefiniowany Program „Cyfrowa Kopalnia” to:

- autorskie spojrzenie specjalistów CNP EMAG na produkcję górniczą dzięki procesom biznesowym wykorzystującym technologie ICT,

- propozycja rozwiązania będącego balansem pomiędzy nowoczesną technologią i możliwością zastosowania jej z uwzględnieniem istniejących uwarunkowań (politycznych, ludzkich i technologicznych),

- wykorzystanie wiedzy kadry i olbrzymiej ilości zgromadzonych danych do znalezienia rozwiązań wspomagających, a nie ingerujących w bieżące procesy produkcyjne,

- kooperacja firm okołogórniczych z KGHM, PGG i JSW w celu osiągnięcia wspólnego sukcesu,

- wdrożenie konkretnych rozwiązań ICT realizowanych przez różnych dostawców usług i technologii.

Kluczową cechą proponowanego programu musi być jego interoperacyjność. Produkty programu będą zdolne funkcjonować w pełnej zgodności $\mathrm{z}$ innymi produktami/systemami, które istnieją lub mogą zaistnieć, bez ograniczonych możliwości implementacji [5].

Interoperacyjność programu zostanie osiągnięta przez zapewnienie:

- interoperacyjności prawnej - przy współpracy z jednostkami certyfikującymi i WUG w celu znalezienia, certyfikowania i dopuszczenia do górnictwa realnych rozwiązań,

- interoperacyjności biznesowej - koordynacji procesów biznesowych i reguł postępowania w obszarze zarządczym, objętym programem,

- interoperacyjności informacyjnej/semantycznej znalezienie realnego systemu informacyjnego przy jednoznacznej interpretacji danych przez systemy stosowane w obszarze zarządczym,

- interoperacyjności technicznej - współpracy wielu maszyn i urządzeń z wykorzystaniem Internetu Rzeczy, zgodnej z założeniami koncepcji Przemysłu 4.0. 


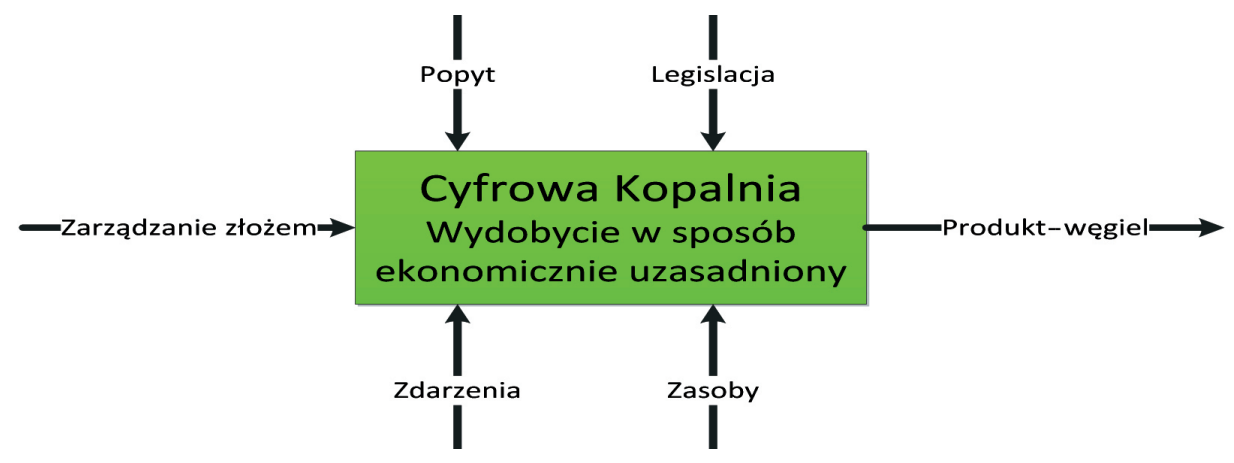

Rys. 1. Idea Programu „Cyfrowa Kopalnia”

Ideę Programu „Cyfrowa Kopalnia” prezentuje rysunek 1, z którego wynika, że cyfryzacja kopalni powinna wspomagać ekonomicznie uzasadnione wydobycie surowca $w$ warunkach istniejącego popytu oraz obowiązujących uwarunkowań legislacyjnych poprzez racjonalne sczerpywanie złoża i efektywne wykorzystanie zasobów, uwzględniając istniejące zagrożenia naturalne [6].

Zakłada się, że realizacja programu będzie stanowić istotny wkład w proces transformacji systemu zarządzania górnictwem.

W trakcie prowadzonych prac zdefiniowano następujące cele szczegółowe programu:

- zwiększenie efektywności zarządzania produkcją górniczą;
- podniesienie bezpieczeństwa środowiska pracy;

- obniżenie kosztów produkcji, ale nie tylko w wartości bezwzględnej, lecz jako procent ceny sprzedaży produktu (węgla, miedzi i innych surowców naturalnych);

- poprawa jakości produktu finalnego dostarczanego klientom końcowym.

Cyfryzacja obszaru zarządzania produkcją i bezpieczeństwem kopalni musi być ukierunkowana na kluczowe procesy biznesowe zachodzące w przedsiębiorstwie wydobywczym.

Procesy biznesowe korporacji górniczej przedstawiono na rysunku 2, zaś na rysunku 3 wskazano, które procesy zostaną objęte programem.

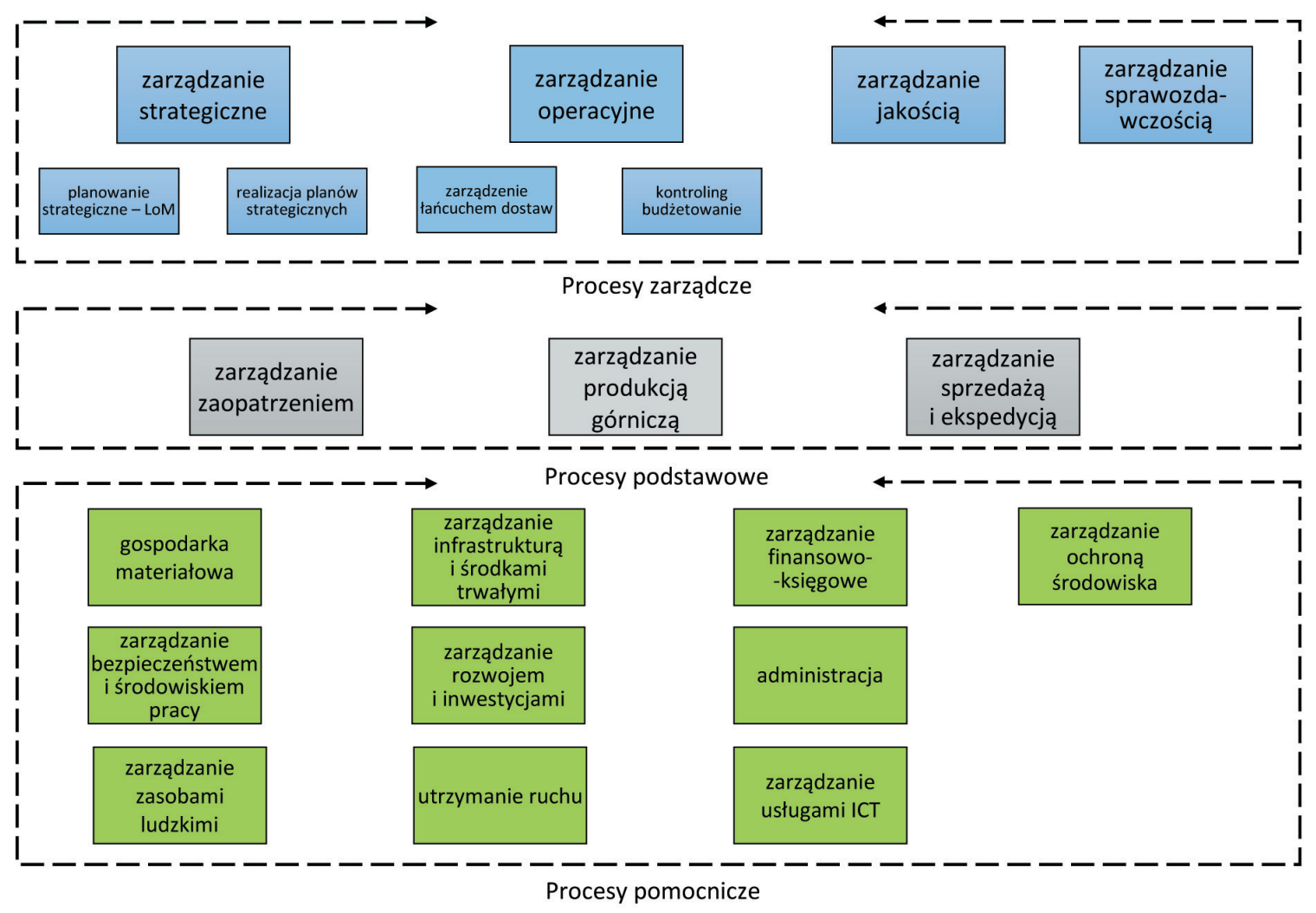

Rys. 2. Mapa procesów korporacji górniczej 


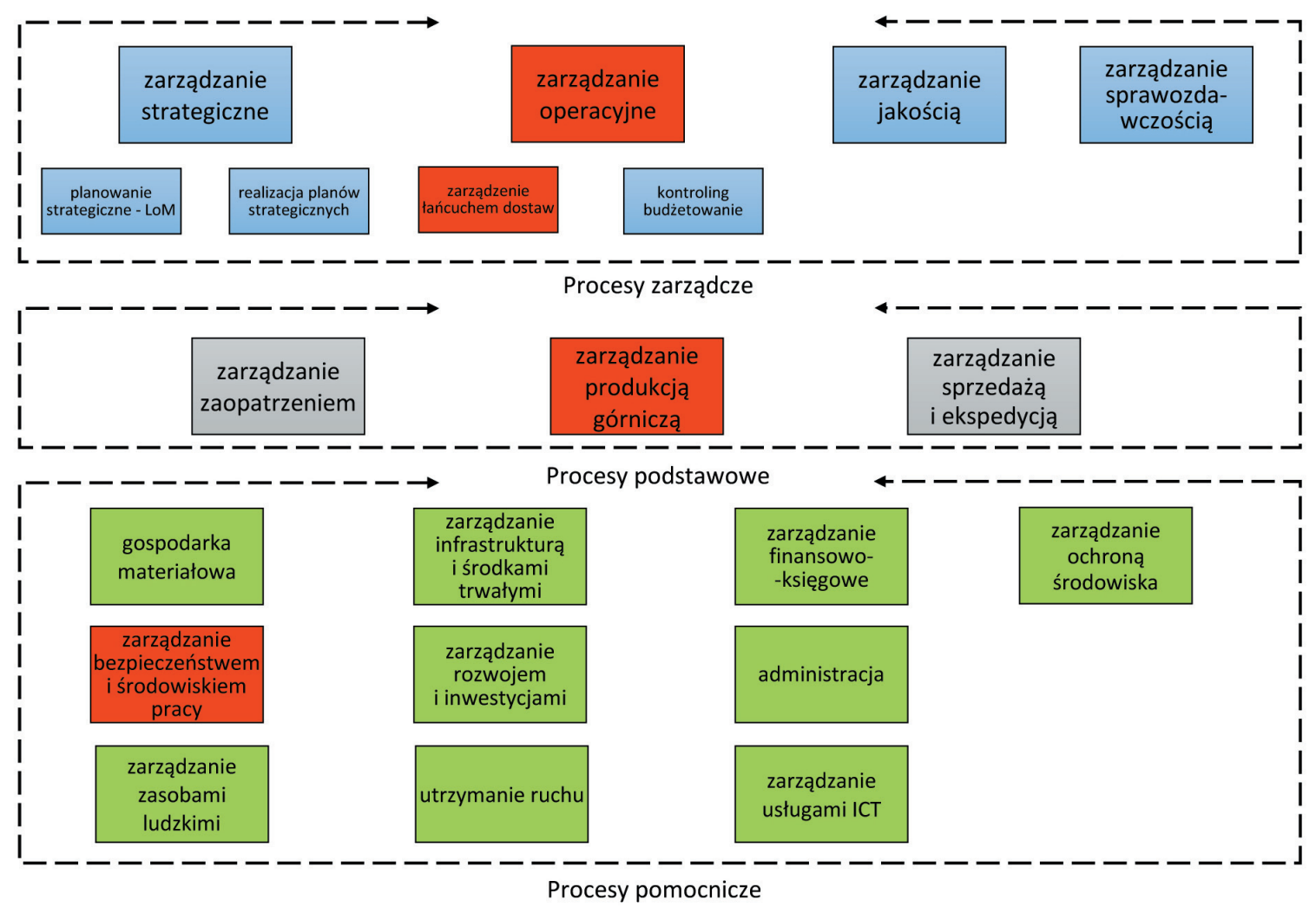

Rys. 3. Procesy biznesowe objęte programem - zaznaczone kolorem czerwonym

Należy podkreślić, że procesy zarządcze, a również wiele funkcjonalności pozostałych procesów jest realizowana na poziomie kierownictwa (zarządu) spółki, a nie w poszczególnych kopalniach (wchodzących w skład spółki).

Ponadto należy zwrócić uwagę na to, że wiele funkcjonalności jest już wspomaganych przez użytkowane systemy informatyczne, np. SZYK 2.

Przedmiotem programu jest cyfryzacja procesów biznesowych przedstawionych na rysunku 3 [5]. Procesy te zaznaczono na rysunku 3 kolorem czerwonym. Procesy intensywnie wspomagane przez obecnie użytkowane systemy informatyczne, a jednocześnie będące przedmiotem programu, zaznaczone cieniem czerwonym.

Założono, że program będzie tworzyć sześć komponentów funkcjonalnych (podprogramów):

- komponent 1: złoże - zakres zarządzania złożem,

- komponent 2: SOP/zakres - planowanie łańcucha dostaw,

- komponent 3: produkcja - zakres zarządzania produkcją górniczą,

- komponent 4: maszyny - zakres zarządzania infrastrukturą oraz utrzymanie ruchu,

- komponent 5: bezpieczeństwo - zakres zarządzania bezpieczeństwem,

- komponent 6: analityka - zakres systemu analiz technicznych (TAS - Technical Analysis System).
Strukturę programu oraz procesy biznesowe powiązane $\mathrm{z}$ jego komponentami przedstawiono na rysunku 4.

Każdy z komponentów programu jest ściśle określony przez funkcjonalności wyspecyfikowanych procesów biznesowych. Komponenty programu powstaną w wyniku zrealizowania stosownych projektów. Można założyć, że zakres funkcjonalny komponentu będzie zrealizowany przez jeden lub kilka powiązanych projektów.

Założono, że poszczególne komponenty funkcjonalne programu będą realizowane przez czołowe jednostki akademickie i instytuty PAN oraz instytuty badawcze i firmy zaplecza górniczego posiadające odpowiednie kompetencje w obszarze górnictwa i ICT, a także największych producentów maszyn górniczych oraz Grupę CNP EMAG.

Szczegółowe funkcjonalności komponentów powinny zostać zdefiniowane w ramach prac fazy przygotowania programu. Prace te powinni zrealizować wstępnie wybrani wykonawcy. Należy podkreślić, że w przypadku realizacji programu przez wielu wykonawców konieczne jest zapewnienie spójności rozwiązania, aby możliwe było osiągnięcie założonego celu.

Spójność rozwiązania zostanie utrzymana dzięki działaniom komitetu sterującego zarządzającego realizacją programu. 


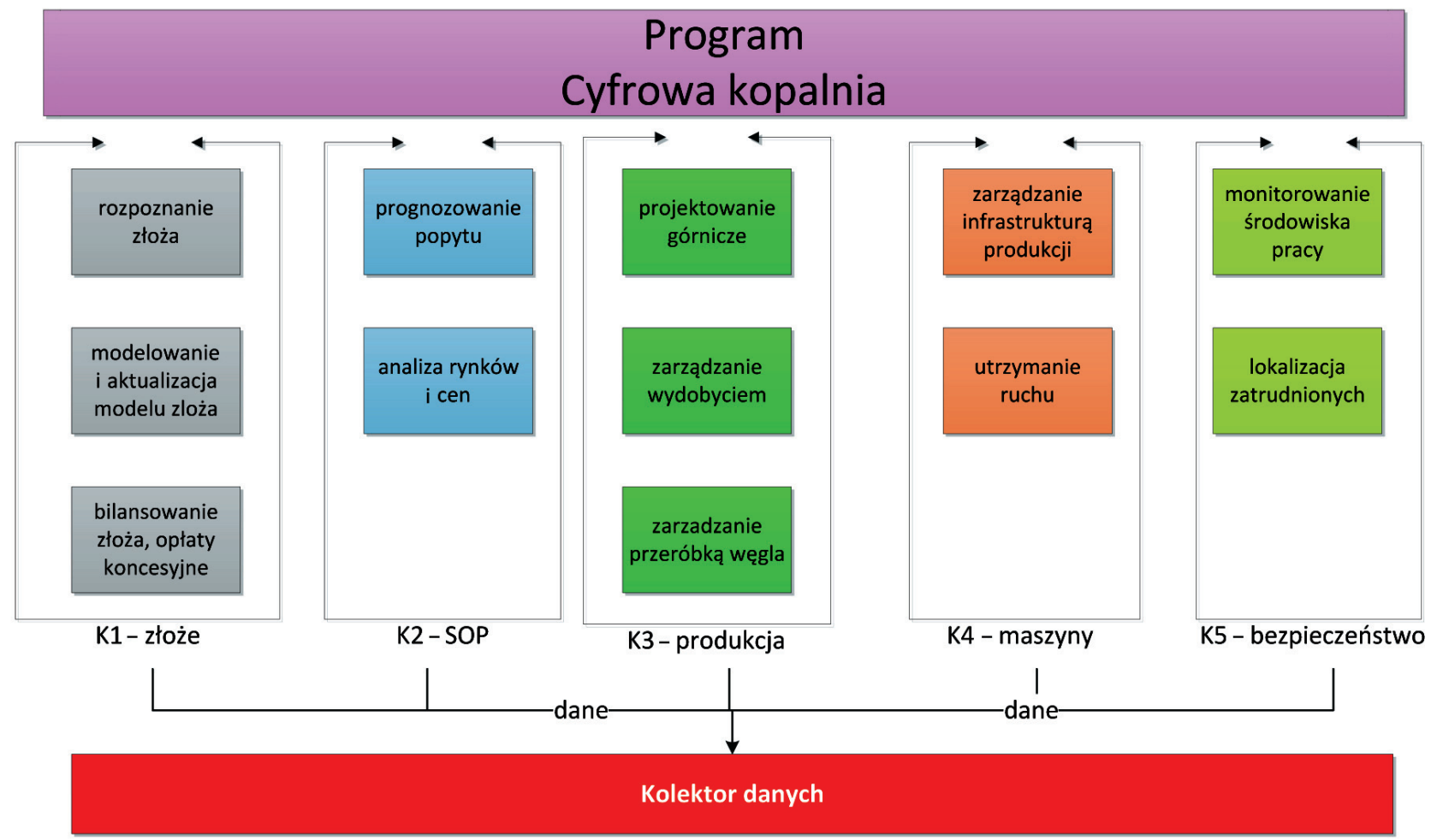

K6 analityka

\section{Rys. 4. Komponenty i procesy biznesowe Programu „Cyfrowa Kopalnia”}

Model procesów po jego opracowaniu przez powołany zespół projektowy powinien zostać zaakceptowany przez komitet sterujący programu i przyjęty jako referencyjny. Model referencyjny będzie determinował zakres prac wykonawców komponentów funkcjonalnych programu. Model referencyjny będzie podstawą stałego rozwoju i doskonalenia realizowanego programu.

Zastosowanie modelu referencyjnego procesów biznesowych do produkcji górniczej umożliwi spełnienie wymagań w zakresie korporacyjnej interoperacyjności biznesowej.

Oczekiwane są następujące rezultaty wdrożenia wyników programu:

- wzrost konkurencyjności i efektywności zarządzania produkcją górniczą w wyniku synchronizacji operacji w ramach całego łańcucha dostaw (od zarządzania złożem do ekspedycji węgla z kopalni),

- udostępnienie narzędzi do prowadzenia racjonalnej gospodarki zasobami oraz złożem przez wdrożenie kompleksowego planowania (od harmonogramów do planów wieloletnich) oraz monitorowania operacji,

- obniżka kosztów produkcji oraz zapewnienia bezpiecznych i właściwych warunków pracy w wyniku bieżącej analizy i monitorowania operacji,
- wzrost wydajności pracy przez zapewnienie lepszych parametrów klimatyzacji (temperatura, zapylenie) pracy w wyrobiskach,

- podniesienie poziomu bezpieczeństwa pracy załóg m.in. w wyniku ograniczenia przebywania w szczególnie niebezpiecznych miejscach (zastosowanie Internetu Rzeczy).

Spodziewane efekty finansowe z realizacji programu to 5-procentowa obniżka kosztów operacyjnych procesów w sferze produkcji i bezpieczeństwa.

\section{SYSTEM ANALIZ TECHNICZNYCH}

Biorąc pod uwagę koszty, złożoność i wymagane prace przygotowawcze uruchomienia programu cyfryzacji górnictwa, proponuje się w pierwszej kolejności wdrożenie projektu, którego produktem będzie system analityczny wykorzystujący dostępne dane ze stosowanych obecnie systemów eksploatacji w kopalniach. Projekt ten będzie bazował na doświadczeniach oraz kompetencjach specjalistów firm Grupy CNP EMAG. Opracowany system analiz technicznych (TAS) będzie realizacją założeń komponentu analitycznego Programu „Cyfrowa Kopalnia”. 
Korzystając z danych obszaru gazometrii, geofizyki, analiz jakości kopaliny, monitorowania maszyn oraz systemów lokalizacji ludzi i urządzeń, będzie można sprawnie przygotować i wdrożyć pierwszy komponent programu.

\subsection{Dane źródłowe systemu TAS}

Założono, że pierwszy etap budowy systemu TAS zostanie ukierunkowany na gromadzenie, przetwarzanie i analitykę danych ustrukturyzowanych pochodzących z systemów obszaru gazometrii, geofizyki oraz monitorowania pracy maszyn i urządzeń.

Kluczowym zagadnieniem projektu w zakresie pierwszego etapu budowy systemu TAS jest opracowanie rozwiązania wspomagającego rozpoznanie i ocenę poziomu zagrożenia w środowisku górniczym, dotyczącego zmian składu powietrza i zjawisk sejsmicznych zachodzących w wyrobiskach podziemnych.

Zmieniające się parametry atmosfery w wyrobiskach górniczych wymagają ciągłej kontroli stężenia tzw. gazów kopalnianych oraz przepływów powietrza. Prowadzone jest ciągłe monitorowanie stanu parametrów za pomocą systemów gazometrii automatycznej wyposażonych w czujniki pomiarowe, koncentratory danych i układy wykonawcze. Dane, za pomocą układów transmisji danych, są przesyłane na powierzchnię do systemów nadzoru dyspozytorskiego.

Można szacować, że polskie kopalnie posiadają ponad 4500 sztuk (średnio 120-150 sztuk w kopalni) metanomierzy $\mathrm{z}$ rejestracją danych, co informuje o skali i złożoności zagadnienia.

Stosowane w polskim górnictwie systemy sejsmiczne umożliwiają lokalizację zjawisk sejsmicznych oraz wyznaczenie parametrów ognisk wstrząsów. Znajomość parametrów sejsmicznych oraz geometrii sieci pomiarowej umożliwia stosowanie różnych algorytmów prędkościowej i tłumieniowej tomografii pasywnej. W algorytmach tomografii wykorzystuje się naturalne zjawiska sejsmiczne wywoływane eksploatacją górniczą. System wyposażony jest w oprogramowanie do tomografii pasywnej metodą inwersji probabilistycznej. Wiarygodność uzyskiwanych wyników w dużym stopniu uzależniona jest od liczby wstrząsów i ich przestrzennego rozkładu.

Użytkowane w kopalniach systemy zapewniają rejestrację danych i komunikatów w lokalnych bazach danych. Bazy danych są kopiowane w kilku archiwach. Dane te wykorzystywane są w dziedzinowych systemach monitorowania i ostrzegania.
Biorąc pod uwagę dostępne dane pomiarowe z kopalnianych systemów monitorowania, postuluje się zbudowanie systemu TAS, który rozszerzy zakres wykorzystywania informacji w celach biznesowych. System będzie zasilany danymi pozyskanymi z kopalnianych systemów monitorowania i rejestrowania danych technicznych.

W systemie TAS zostaną zgromadzone ogromne ilości danych z monitoringu gazowego i sejsmicznego. Setki urządzeń zainstalowanych w kopalniach mierzą i monitorują stężenie metanu w powietrzu (duże ilości pomiarów ciągłych), stężenia pyłu węglowego oraz gazów: $\mathrm{CO}, \mathrm{CO}_{2}, \mathrm{H}_{2} \mathrm{~S}, \mathrm{NO}_{2}, \mathrm{O}_{2}$. Mierzone są prędkości przepływów powietrza do oceny warunków pracy urządzeń wentylacyjnych, wilgotności, temperatury powietrza i skał oraz temperatury zastępczej czy ciśnienia atmosferycznego.

Podobnie gromadzone są dane pomiarowe z kilkudziesięciu sejsmometrów dwu- i trójskładowych oraz geofonów, które trafiają do grupy dyspozytorów - ekspertów nadzorujących zjawiska tąpaniowe w kopalniach.

Znaczna będzie również ilość informacji gromadzonych w systemie TAS z zakresu monitorowania pracy i stanu technicznego maszyn/urządzeń. Na przykład dla PGG należałoby założyć gromadzenie danych dla:

- 8000 obudów zmechanizowanych,

- 47 kombajnów ścianowych,

- 88 kombajnów chodnikowych,

- 1300 układów transportujących,

- 270 podziemnych kolejek.

Dane $\mathrm{z}$ tych pomiarów będą stanowić zasilenie informacyjne dla systemu TAS. System TAS będzie również zasilany danymi pozyskanymi z zewnętrznych systemów. Zakłada się, że Centrum Krajowe EPOS (European Plate Observing System) zapewni kompleksowo zunifikowane dane z konkretnej dziedziny (np. sejsmologiczne, geodezyjne, geologiczne) [7].

W kolejnym etapie rozwoju systemu TAS zostaną opracowane rozwiązania potrzebne do gromadzenia, przetwarzania oraz analityki danych nieustrukturyzowanych, takich jak:

- mapy geologiczne,

- dokumentacja górnicza (dane historyczne),

- dane generowane przez systemy pomiarowe oraz automatyki,

- dane geolokalizacyjne, generowane przez mobilne urządzenia lokalizacji ludzi oraz maszyn,

- dane pochodzące $\mathrm{z}$ internetu,

- fotografie i skany,

- dane pochodzące z innych systemów. 
Należy podkreślić, że dane gromadzone w systemie TAS będzie cechować duża ilość i zmienność w czasie oraz nieoceniona wartość biznesowa, która może być pozyskana w procesie analizy i wnioskowania.

Szczegółowy zakres danych źródłowych zostanie zdefiniowany w trakcie opracowywania projektu.

\subsection{Technologia systemu TAS}

Przyjęto założenie, że system TAS powinien gromadzić dane zarówno ustrukturyzowane, jak i nieustrukturyzowane, pochodzące $\mathrm{z}$ górniczych systemów technicznych oraz zewnętrznych źródeł danych (np. EPOS). Składowanie, przetwarzanie oraz narzędzia analityczne systemu powinny umożliwić pozyskanie $\mathrm{z}$ danych konkretnej informacji, istotnej dla poprawy efektywności procesów biznesowych w korporacji górniczej.

W pierwszej kolejności zostanie opracowany system TAS oparty na technologii BI (Business Inteligence). Schemat struktury systemu w technologii BI przedstawiono na rysunku 5. Opracowane rozwiązanie analityczne powinno umożliwić przeprowadzanie zaawansowanych analiz oraz zastosowanie metod prognozowania.

W kolejnym etapie zakres danych źródłowych zostanie rozszerzony o dane nieustrukturyzowane. Wy- magać to będzie rozwinięcia systemu TAS o nową technologię, zgodnie ze schematem przedstawionym na rysunku 6. Zostanie zastosowana technologia określana jako Big Data.

Zastosowanie danych nieustrukturyzowanych wiąże się z koniecznością poznania możliwości zastosowania systemu szkieletowego Hadoop (oprogramowania typu open-source) do zbudowania własnego środowiska analitycznego obsługującego masowe, górnicze dane tego typu. Prace projektowe będą prowadzone w celu opracowania metody łączenia danych w różnych formatach i strukturach, aby możliwe było znalezienie niewidocznych obecnie relacji i zależności. Na podstawie ogólnie stosowanej technologii BI nie jest możliwe przetwarzanie tego typu danych nieustrukturyzowanych $\mathrm{w}$ rozsądnym czasie, $\mathrm{z}$ uwagi na brak specjalistycznych narzędzi analitycznych, dostosowanych do przewidywanej wielkości zbiorów i specyfiki analizowanych górniczych zagadnień.

W strukturze rozwiązania technologicznego systemu TAS należy wyróżnić warstwę danych źródłowych, danych transakcyjnych z systemów pomiarowych i monitorowania. Dane te w wyniku realizacji procesu ETL (Extract, Transform and Load) zostaną oczyszczone, zintegrowane i dostosowane do wymagań hurtowni danych. W proponowanym rozwiązaniu zakłada się, że dane zostaną załadowane do Hurtowni Danych Korporacyjnych.
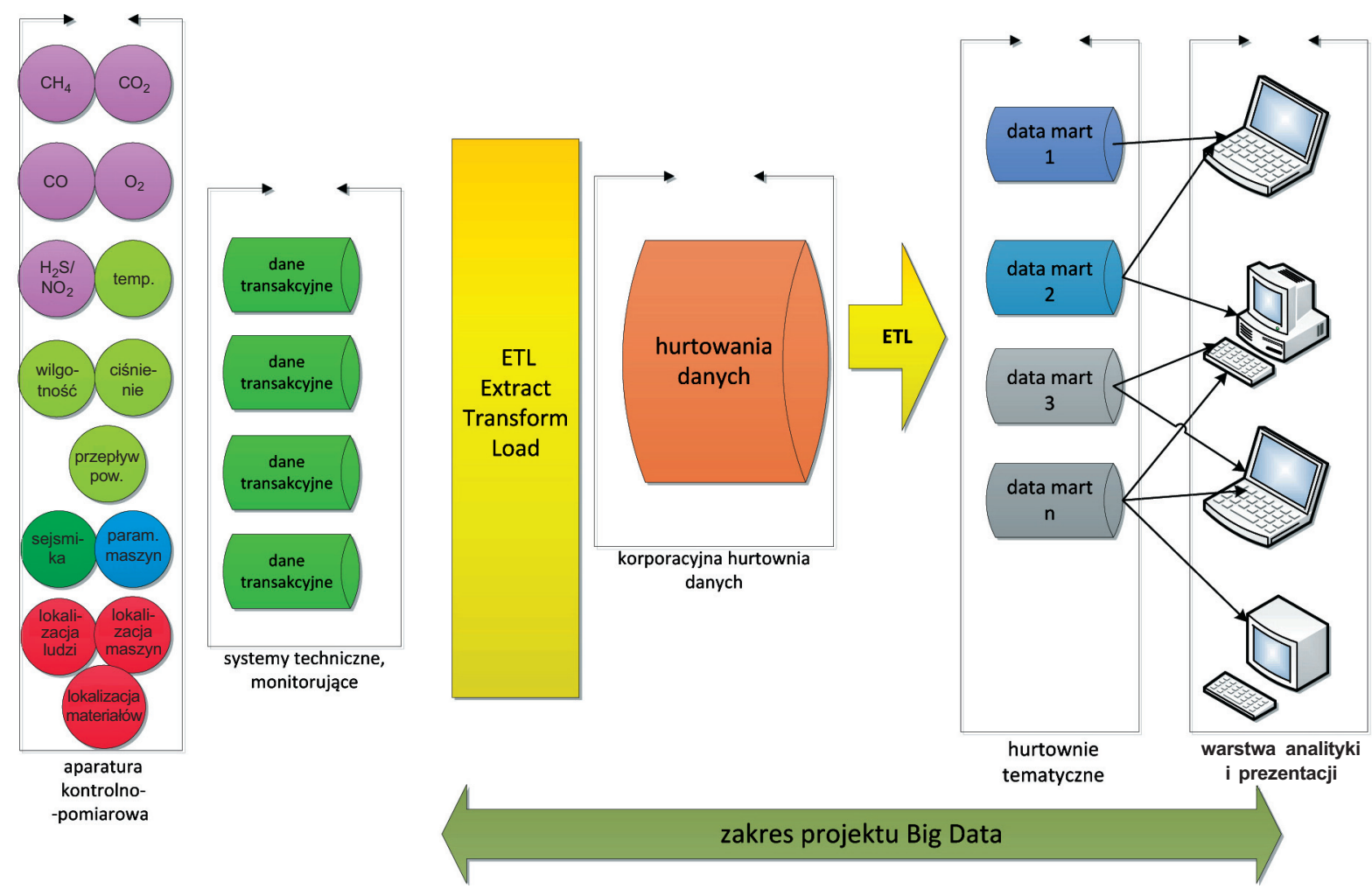

Rys. 5. System TAS w technologii BI 


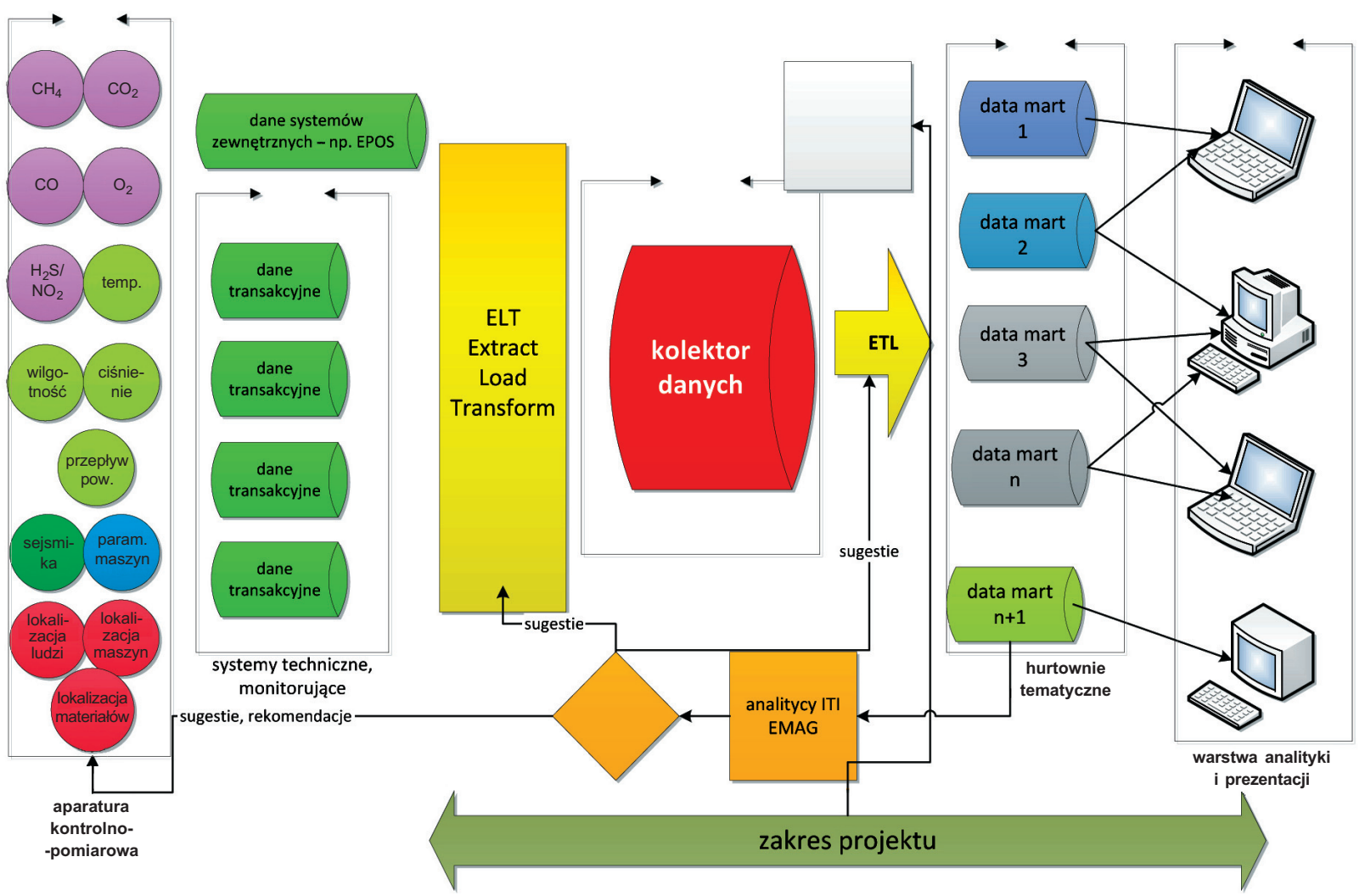

Rys. 6. System TAS w technologii Big Data

Pochodzące z wielu źródeł dane w hurtowni zostaną zintegrowane i przeznaczone wyłącznie do odczytu. W przypadku znacznego zapełnienia Hurtowni Danych (Data Warehouse) danymi oraz dla usprawnienia analityki tworzone mogą być hurtownie tematyczne, tzw. Data Marts.

Rekomenduje się dwie struktury przechowywania danych w tzw. Data Mart:

- Data Mart bazodanowa - baza jednowymiarowa, przetwarzanie i agregacja danych w aplikacji np. do raportowania;

- struktura wielowymiarowa, w której dane są gotowe do analizy typu OLAP (Online Analytical Processing).

W systemie TAS powszechnie będzie stosowana eksploracja danych (Data Mining) do wyszukiwania trendów i zależności. Rozwiązanie technologiczne oparte na procesie ELT oraz kolektorze danych przedstawiono na rysunku 6.

Metody eksploracji danych powinny umożliwić wykrywanie związków przyczynowo-skutkowych, które nie moga być obecnie identyfikowane $z$ uwagi na ogrom danych do przeanalizowania za pomoca stosowanych technologii. Pozwoli to lepiej eliminować zagrożenia w kopalni oraz poprawić efektywność procesów biznesowych. Model prognozowania zwykle opiera się na danych historycznych pobieranych z hurtowni danych. Podlegają one procesom analizy w module analitycznym. Dane do prowadzenia prognozowania w czasie rzeczywistym muszą być jednak dostępne na bieżąco, a nie w okresach wynikających z cyklów aktualizacji hurtowni. Konieczne jest wówczas zastosowanie procesu ELT (Extract, Load, Transform) zamiast ETL (Extract, Transform, Load) i ładowanie źródłowych danych do kolektora danych lub Data Mart powiązanej bezpośrednio z modułem obsługi prognozowania.

Zastosowanie technologii ELT jest zasadne w przypadku zapisu i przechowywania danych nieustrukturyzowanych w kolektorze systemu TAS, zgodnie z rekomendacjami dla technologii Big Data.

Budowa systemu TAS przy zastosowaniu technologii używanej w systemach typu Big Data wymagać będzie rozpoznania zasadności zastosowania:

- koncepcji MapReduce - platforma Big Data, dostępnej w rozwiązanich Hadoop/ Apache Software Foundation, SAP HANA,

- bazy danych (NoSQL), Apache Hbase - do zapisu strumieni danych,

- oprogramowanie do analizy dużych zbiorów danych nieustrukturyzowanych - Apache Hadoop, SAP HANA (wyszukiwanie zależności i relacji między danymi w różnych formatach i strukturach). 


\subsection{Analityka systemu TAS}

System analiz technicznych powinien zapewnić narzędzia do:

- automatycznego raportowania,

- wyszukiwania danych z filtrowaniem,

- analiz typu ad hoc,

- eksploracji danych (data mining - drill-down, roll-up, drill-across, drill-through),

- budowania modeli prognostycznych (predictive models),

- eksportu plików do Excela.

Możliwość eksportu wybranych plików danych do Excela powinna spełnić oczekiwania tych analityków, którzy traktują Excel jako podstawowe narzędzie do prac analitycznych.

W systemie TAS powszechnie stosowana będzie eksploracja danych (data mining) w celu wyszukiwania trendów i zależności.

Metody eksploracji danych powinny umożliwić wykrywanie związków przyczynowo-skutkowych, które nie mogą być obecnie identyfikowane $\mathrm{z}$ uwagi na ogrom danych do przeanalizowania za pomocą stosowanych technologii. Pozwoli to lepiej eliminować zagrożenia w kopalni oraz poprawić efektywność procesów biznesowych.

Ocena wyniku pomiaru i wiarygodności analizowanych danych musi być prowadzona w kontekście prawdopodobnej dynamiki zmian wielkości mierzonej. Pozwala to uznać wynik pomiarów za prawdopodobny lub nieprawdopodobny. Zachodzi potrzeba zdefiniowania reguł, kryteriów oceny pomiarów, aby weryfikacja poprawności dokonanej oceny była możliwa jedynie na podstawie dalszego przebiegu procesu. W wielu przypadkach, szczególnie dotyczących zagrożeń, taka ocena musi być dokonana w czasie rzeczywistym. Wymusza to szybkość reakcji systemu analitycznego, kojarzącego wyniki bieżących pomiarów z danymi historycznymi oraz działającego zgodnie $\mathrm{z}$ regułami i przepisami górniczymi. Pozyskiwanie danych pomiarowych oraz częstotliwość poboru danych przez system będzie przedmiotem rekomendacji dla wielkości mierzonych. W ramach zadania zostaną zweryfikowane również stosowane reguły agregacji pomiarów, co dotyczy przypadków, gdy pojedynczy wynik pomiarowy reprezentuje wartość wielkości mierzonej $\mathrm{w}$ danym przedziale czasu, większym niż pozyskiwanie danych pomiarowych (okresy agregacji powinny wynikać z praktyki górniczej i przepisów).

Modelowanie predykcyjne pozwala na prognozowanie przyszłych wyników, szacowanie ryzyka, ocenę sytuacji oraz ogólnie pojęte zarządzanie procesami.
Statystyczne analizowanie reprezentatywnych porcji dostępnych informacji w systemie TAS może pomóc w szybkości i jakości rozwijania modelu statystycznego prognozowania.

W ramach projektu powinna zostać dobrana metoda prognozowania dla wybranych, kluczowych, procesów. Przyjmując metody ilościowe prognozowania, można skorzystać m.in. z modeli: szeregów czasowych, ekonometrycznych, analizy kohortowej ze zmiennymi kluczowymi.

Metody jakościowe oparte są na osądach ekspertów i są formułowane na podstawie danych o kształtowaniu się wartości zmiennej prognozowanej i zmiennych objaśniających w przeszłości.

Podstawę wyboru metody prognozowania powinny stanowić przyjęte przesłanki oraz dostępne dane historyczne. Na obecnym etapie definiowania zakresu projektu badawczego można rekomendować metody ilościowe oparte na szeregach czasowych. Jednak w miarę pozyskania doświadczenia w prognozowaniu oraz zgromadzenia danych nierestrukturyzowanych można będzie skorzystać z metod jakościowych. Budowa modelu będzie wspomagana przez moduł obsługi prognozowania. W okresie stosowania prognoz należy prowadzić ocenę trafności prognozy za pomocą błędów ex post. Wyniki prognozowania będą prezentowane $\mathrm{w}$ formie tabel i wykresu wartości prognozowanej. Moduł prognozowania powinien zostać zasilony rzeczywistymi wartościami, które będą mogły być porównane z prognozą.

\subsection{Centrum Analiz Danych}

Komponent analityczny systemu TAS będzie przetwarzał zgromadzone informacje i umożliwiał przeprowadzanie wnioskowania na podstawie zaimplementowanych modeli.

System TAS należy traktować jako narzędzie pomocnicze $\mathrm{w}$ procesach podejmowania decyzji w zagadnieniach technicznych.

Zakłada się, że opracowanie i wdrożenie produktów Programu „Cyfrowa Kopalnia”, a w szczególności wdrożenia systemu TAS będzie powiązane $\mathrm{z}$ uruchomieniem Centrum Analiz Danych (DAC - Data Analysis Centre).

Centrum DAC będzie prowadzić zaawansowane analizy gromadzonych danych z monitorowania procesu produkcji górniczej oraz parametry środowiska pracy górników.

Zakłada się, że w pracach DAC będą uczestniczyć eksperci z różnych jednostek organizacyjnych (wyższych uczelni, instytutów badawczych, WUG i przedsiębiorców górniczych) posiadający stosowną wiedzę. 
Obecnie dostępne technologie ICT w pełni umożliwiają zdalny dostęp do danych oraz zdalne śledzenia procesów w czasie rzeczywistym przez rozproszone zespoły analityczne.

Analitycy z Centrum Analizy Danych powinni:

- posiadać umiejętności do prowadzenia analiz dużych zbiorów danych typu Big Data wykorzystujących dane ustrukturyzowane i nieustrukturyzowane,

- rozumieć „zachowanie” maszyn i sieci pomiarowej, systemów, aby rozróżniać nienaturalne, odbiegające od reguł zdarzenia/przypadki, a jednocześnie nie generować fałszywych alarmów,

- posiadać umiejętności do modelowania prognoz i symulacji,

- posiadać zdolności do interpretacji wyników analiz i prognoz w kontekście wiedzy branżowej, znajomości procesów oraz norm i reguł postępowania.

Centrum DAC będzie świadczyć usługi eksperckie (analizy, modelowanie, prognozowanie) w przypadku technologii Big Data, które będą rozliczane za pomocą systemu billingowego rejestrującego wykonywane prace. Powiązania usług Centrum DAC z systemem TAS zaprezentowano na rysunku 6.

\section{PODSUMOWANIE}

Zaproponowana $\mathrm{w}$ artykule koncepcja programu stopniowej cyfryzacji polskiego górnictwa jest próba kompleksowego rozwiązania umożliwiającego wspomaganie procesów zarządczych, produkcyjnych i zagadnień bezpieczeństwa. Pozwoli to na optymalizację wykorzystania posiadanych maszyn i urządzeń w cyklu produkcyjnym, precyzyjne planowanie remontów $\mathrm{i}$ inwestycji. Podniesie także zdecydowanie bezpieczeństwo pracy w podziemnych zakładach górniczych. Systemowe podejście do zarządzania produkcją i bezpieczeństwem z uwzględnieniem ilościowych i jakościowych aspektów ekonomicznych jest szczególnie istotne dla restrukturyzowanego od lat polskiego górnictwa.

Dobrym przykładem pierwszego etapu cyfryzacji kopalń jest zrealizowanie koncepcji utworzenia One Control Room w ZG Polkowice-Sieroszowice KGHM, który stanowi nowy sposób podejścia do pozyskiwania i przetwarzania gromadzonych danych. Daje możliwość zdalnej kontroli i sterowania procesem produkcyjnym i utrzymaniowym oraz proaktywnego podejścia do utrzymania systemów zapewniających ograniczenie kosztów eksploatacji i podniesienie jakości produktu końcowego [8].
Ze względu na to, że przetwarzanie coraz większych zbiorów danych staje się codzienną praktyką w biznesie, niezbędna jest realizacja kolejnego etapu cyfryzacji górnictwa polegająca na stworzeniu systemu analiz technicznych w technologii Big Data wraz z centrum analizy danych. Znalezienie zależności i korelacje między danymi pochodzącymi z różnych obszarów procesów podstawowych i pomocniczych w kopalni stanie się znakomitym źródłem informacji zarządczych, utrzymaniowych oraz będzie umożliwiać aktywne wpływanie na przebieg procesu produkcji i wymaganą przez klienta jakość produktu końcowego. Równie ważnym elementem jest sposób prezentacji powyższych informacji uwzględniający możliwości percepcyjne osób zarządzających produkcją.

\section{Literatura}

[1] Kozłowski A., Wojtas P.: Systemowe podejście do cyfryzacji $w$ procesach technologicznych $w$ górnictwie, „Szkoła Eksploatacji Podziemnej", Kraków 2017.

[2] Kozłowski A.: Bezpieczeństwo procesów technologicznych $w$ ujęciu systemowym - Zintegrowany system zarzadzania Silesia + , Kongres Innowacji Polskich, Kraków 2015.

[3] Stach R., Borkowski L.: One control room w ZG Polkowice-Sieroszowice, IMF, Jastrzębie-Zdrój 2017.

[4] Kozłowski A., Wojtas P.: Możliwość optymalizacji procesów technologicznych zakładu górniczego $w$ kontekście cyfryzacji górnictwa, Polski Kongres Górniczy, Kraków 2017.

[5] Goleń A., Gałuszka J., Wojtas P., Wojtas M.: Studium Wykonalności Programu Cyfrowa Kopalnia/ Smart Mine, opracowanie własne CNP EMAG S.A., Katowice 2017.

[6] Wojtas P., Goleń A.: Optymalizacja procesów wydobywczych poprzez cyfryzację kopalni, IMF, Jastrzębie-Zdrój 2017.

[7] European Research Infrastructure on Solid Earth, https:// www.epos-ip.org/.

[8] Andrzejewski M., Borkowski L.: Kierunki rozwoju monitoringu pracy maszyn $i$ urzadzeń górniczych w KGHM „Polska Miedź” S.A., „Wiadomości Górnicze” 2014, 10: 550-556.

dr inż. PIOTR WOJTAS

Centrum Naukowo-Przemystowe EMAG S.A. ul. Karoliny 4, 40-186 Katowice piotr.wojtas@cnp-emag.pl

dr inż. ARTUR KOZŁOWSKI Instytut Technik Innowacyjnych EMAG ul. Leopolda 31, 40-189 Katowice artur.kozlowski@ibemag.pl

mgr MAREK WOJTAS

TELVIS Przedsiębiorstwo Ustugowo-Produkcyjne

Sp. $z$ o.o.

ul. Karoliny 4, 40-186 Katowice marek.wojtas@telvis.pl 